\title{
SPE-HPLC Method for Determination of Ketoconazole and Clotrimazole Residues in Cow's Milk
}

\author{
Farzaneh Ahmad Khan Beigi, ${ }^{a, b}$ Mohammad Imani, ${ }^{* a}$ Mahmood Payehghadr ${ }^{b}$ and \\ Hedayat Hosseinic
}

${ }^{a}$ Novel Drug Delivery Systems Dept., Iran Polymer and Petrochemical Institute, P.O. Box 14965-115, Tehran, Iran

${ }^{b}$ Payame Noor University (PNU), Karaj, Iran

${ }^{c}$ Food Science \& Technology Dept., National Nutrition \& Food Technology Research Institute, Shahid Beheshti University of Medical Sciences, P.O. Box 19395-4741, Tehran, Iran

Um método simples confirmatório para determinação em HPLC-UV de resíduos de cetoconazol e clotrimazol em leite de vaca, após extração da fase sólida (SPE), é relatado neste artigo. Foram removidos das amostras proteínas e lipídeos por tratamento com acetonitrila e conseqüente extração em $n$-hexano. Os extratos foram posteriormente limpos e concentrados através de extração em fase sólida. Os analitos foram determinados quantitativamente usando um método validado de cromatografia líquida de alta eficiência. O método foi linear no intervalo de 0,1 a $1,0 \mu \mathrm{g} \mathrm{mL}^{-1}$ para ambos analitos. Os limites de detecção e quantificação para os analitos foram iguais a 0,01 e $0,1 \mu \mathrm{g} \mathrm{mL} \mathrm{mL}^{-1}$, respectivamente. Parâmetros importantes que influenciam a eficiência da extração foram investigados e otimizados. O método proposto foi aplicado à análise de amostras de leite. Foram obtidas recuperações satisfatórias no intervalo de 95,9 a 101,78\%, usando SPE.

A simple confirmatory method for HPLC-UV determination of ketoconazole and clotrimazole residues in cow's milk after solid phase extraction (SPE) is reported in this article. The samples were deprived of proteins and lipids by treating with acetonitrile and consequent extraction in $n$-hexane. Extracts were further cleaned-up and concentrated via solid phase extraction. The analytes were determined quantitatively using a validated high performance liquid chromatography method. The method was linear in the range of $0.1-1.0 \mu \mathrm{g} \mathrm{mL^{-1 }}$ for both analytes. Limits of detection and quantification for both analytes were equal to 0.01 and $0.1 \mu \mathrm{gL}^{-1}$, respectively. Important parameters influencing the extraction efficiency were investigated and then optimized; the proposed method was applied to the analysis of milk samples. Satisfactory recoveries were obtained in the range of 95.9-101.78\% using SPE.

Keywords: ketoconazole, clotrimazole, solid-phase extraction, high performance liquid chromatography, milk

\section{Introduction}

Administration of veterinary drugs for treatment of food-producing animals, can significantly affect public health and international trade of food products, due to the presence of drug residues or their metabolites in milk, eggs, meat etc. Misuse of drugs and/or giving not adequate time after treatment for drug clearance, possibly leads to the presence of their residues in milk and increases the potential risk to consumers, due to the allergic reactions of those who are sensitive to those drugs e.g., antibiotics. ${ }^{1,2}$

*e-mail: m.imani@ippi.ac.ir
Ketoconazole (KET) (Figure 1A) and clotrimazole (CLO) (Figure 1B) are synthetic imidazole derivatives with a broad-spectrum of antifungal activity. First developed in 1969, topical preparations containing CLO are routinely

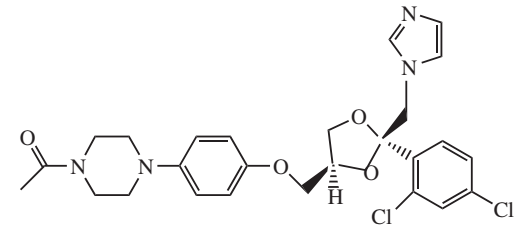

(A)

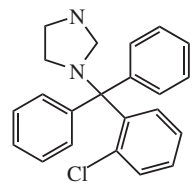

(B)
Figure 1. Chemical structures of (A) ketoconazole and (B) clotrimazole. 
used for treatment of various systemic mycoses including candidiasis. ${ }^{3,4}$ The compound is highly effective, but can alter liver enzymatic activity. ${ }^{5-8}$

The major problem concerning analysis of drug residues in milk is complexity of this analytical matrix. ${ }^{1}$ Milk is a complex fluid containing all nutrients required for growth and development of newborns, for example specific proteins, easily digestible fats, vitamins, and other components that may play an important role, all these may interfere with an analyte recovery.

Methods for monitoring drug residues in veterinary products should be rapid, specific and sensitive enough to enable detection at very low levels. It is also necessary to develop and optimize analytical methods for detection of residues at low concentration levels. Solid phase extraction (SPE) is a relatively rapid, easy and inexpensive method of extraction which has been shown to be applicable in extraction of drug residues from biological matrices, including fatty matrices, e.g., milk. ${ }^{9}$

Several SPE methods for extraction of azole antifungal drugs from plasma, serum and biological samples were reported $;^{10,11}$ however, no report on application of SPE for separation of antifungal drug residues from dairy products appeared in the literature to the best of the authors' knowledge. Extraction of CLO residue from environmental samples, i.e., water, is reported by Paull and co-workers, ${ }^{12}$ using an optimized SPE procedure which was subsequently analyzed by HPLC using a monolithic column. A solid phase extraction procedure is also reported for clean-up and sample preconcentration of antifungal agents including KET, CLO, itraconazole, fluconazole, and voriconazole and their metabolites after incubation with human parenchymal hepatocytes. ${ }^{13}$ Extraction of miconazole from human plasma was performed by SPE. ${ }^{14}$ Several methods for determination of CLO and KET have been described in the literature including volumetric, ${ }^{15}$ spectrophotometric, ${ }^{16,17}$ spectrofluorimetric, ${ }^{18,19}$ capillary electrophoresis, ${ }^{20,21}$ thin layer chromatography, ${ }^{22}$ gas chromatography ${ }^{23}$ and high performance liquid chromatography methods..$^{24,25}$ This paper describes the development and optimization of a new analytical method combining SPE of CLO and KET residues in milk from dairy cattle and their subsequent analysis by a previously validated HPLC-UV method.

\section{Experimental}

\section{Instrumentation}

Samples were analyzed using an Agilent 1200 high performance liquid chromatograph (Agilent, USA) consisting of degasser, G1312B binary pump system, autosampler and G1316B TCCS1 column oven. It was coupled with UV-Visible detector and controlled by Agilent Chemstation ${ }^{\circledR}$ software. Separation of KET and CLO were achieved using a Zorbax Eclipse XDB-C18 column (particle size $5 \mu \mathrm{m}, 250 \times 4.6[1 \times$ i.d. $]$ ) equipped with Zorbax C18 analytical guard column $(12.5 \mathrm{~mm} \times 4.6 \mathrm{~mm})$ at $35^{\circ} \mathrm{C}$. All injections were performed automatically using a $20 \mu \mathrm{L}$ loop on an Agilent C1329A ALS autosampler apparatus. Detection of the analytes was carried out using Agilent multiwavelength UV detector (G1365C MWDSL, Agilent, USA) at $212 \mathrm{~nm}$. The analytes were separated by running a mobile phase consisted of acetonitrile and $20 \mathrm{mmol} \mathrm{L}^{-1}$ sodium acetate buffer ( $\mathrm{pH} 4.6$ ) at a flow rate of $1 \mathrm{~mL} \mathrm{~min}^{-1}$ through the column. The composition was held constant at $(85: 15 \mathrm{v} / \mathrm{v})$ to give a total run time of $5.5 \mathrm{~min}$. All experiments were employed in the same isocratic mode and all calculations concerning the quantitative analysis were performed with external standardization by measurement of peak areas. Calibration curve was drawn using six concentrations of the analytes, separately. All analyses were replicated three times. A brief description of HPLC method validation results is given in Table 1 .

For solid phase extraction, $\mathrm{C}_{18}$ Sep-Pak cartridges (WAT036575, 55-105 $\mu \mathrm{m}$, Waters, USA), extraction tank and manifold (Waters, Milwaukee, USA) were used. $\mathrm{pH} /$ Ion meter (Model 781, Metrohm, Switzerland), electronic precision balance (Model 770, KERN, Switzerland) and centrifuge (SIGMA 2-16K, Sigma, Germany) were also used.

\section{Chemicals and reagents}

Ketoconazole and clotrimazole (USP XXIII) were obtained from FDC (India). KET (LOT \# H0F084) and CLO (LOT \# K0C280) certified reference standards were obtained from United States Pharmacopeia Convention (Maryland, USA). Methanol, ethanol, acetone, chloroform, acetonitrile (ACN) were of HPLC grade and purchased from Romil (Loughborough, UK). Glacial acetic acid and sodium acetate (both of analytical grade) were obtained from Merck Chemicals (Darmstadt, Germany). Sodium chloride pellets (analytical grade) was obtained from Merck. Water (HPLC grade) was produced in-house. All water used was doublydeionized water (AquaMax Ultra 370 water purification systems, YoungLin, Anyang, South Korea).

\section{Preparation of standard solutions}

Individual standard stock solutions $\left(1000 \mu \mathrm{g} \mathrm{mL}^{-1}\right)$ were prepared by weighing $10 \mathrm{mg}$ of KET and CLO into $10 \mathrm{~mL}$ volumetric flasks, and dissolving in methanol. Stock 
Table 1. HPLC-UV method validation parameters for analysis of clotrimazole and ketoconazole

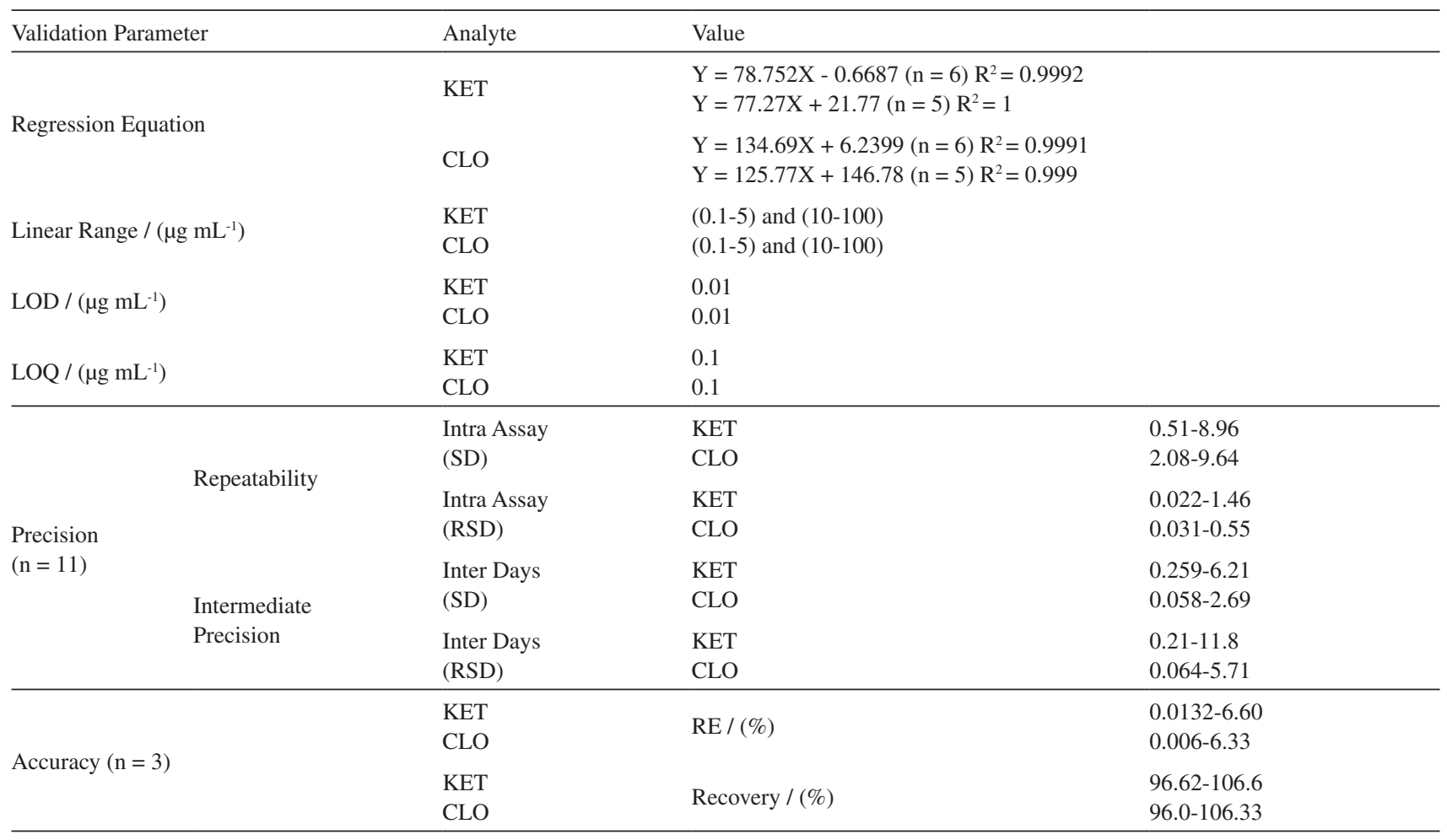

solutions were stored at $4{ }^{\circ} \mathrm{C}$ for not longer than 2 weeks. A working standard solution $\left(10 \mu \mathrm{g} \mathrm{mL}^{-1}\right)$ was prepared by pouring $100 \mu \mathrm{L}$ of each standard stock solution to a single $10 \mathrm{~mL}$ volumetric flask and diluting to volume with doublydeionized water. Working solution was prepared daily and stored at $4{ }^{\circ} \mathrm{C}$ prior to use.

\section{Extraction procedure}

Cow's milk samples provided from local market and then were stored at $-14{ }^{\circ} \mathrm{C}$ before use and defrosted at room temperature for analysis. Milk sample $(5 \mathrm{~mL})$ was added into a $50 \mathrm{~mL}$ centrifuge tube. For samples spiked with drugs, $1 \mu \mathrm{g} \mathrm{mL}^{-1}$ of the working solution was added to the blank cow's milk sample. ACN (15 mL) was added, shook and centrifuged. The supernatant was transferred into another $50 \mathrm{~mL}$ centrifuge tube and $10 \mathrm{~mL}$ of $n$-hexane was added. The centrifuge tube was then shook for $15 \mathrm{~min}$ and centrifuged at $5000 \mathrm{rpm}$ for $15 \mathrm{~min}$ at $20{ }^{\circ} \mathrm{C}$. The top hexane layer was removed, and the middle layer, a mixture of ACN and water containing imidazole residues, was transferred into another tube by pipetting. ACN was removed using a stream of nitrogen at $50{ }^{\circ} \mathrm{C}$ in a water bath. After approximately $45 \mathrm{~min}$, about $3 \mathrm{~mL}$ of the aqueous solution remained in the test tube; $10 \mathrm{~mL}$ of water was added to reconstitute the sample extracts. Cartridges were preconditioned sequentially with $10 \mathrm{~mL}$ of methanol and water, $5 \mathrm{~mL}$ of $2 \% \mathrm{NaCl}$, and $10 \mathrm{~mL}$ of phosphate buffer ( $\mathrm{pH}$ 5.8). The reconstituted solution was loaded on the preconditioned cartridge under vacuum. Finally, ketoconazole and clotrimazole were eluted from the cartridges using ethanol. The SPE cartridges were eluted with $5 \mathrm{~mL}$ of ethanol and the resulting eluent was transferred to $10 \mathrm{~mL}$ test tubes and blown with transmission of $\mathrm{N}_{2}$ gas flow at $50{ }^{\circ} \mathrm{C}$ in a water bath until complete drying. Finally, the extract was mixed with $1 \mathrm{~mL}$ of ACN, shook for $30 \mathrm{~s}$ and, sonicated to complete dissolution and then analyzed by HPLC-UV with an injection volume of $20 \mu \mathrm{L}$.

\section{Results and Discussion}

Presence of bioactive residues in food chain can impose huge risks to consumers. Several methods have been previously reported to separate and analyze anti-fungal drug residues in plasma and lung, liver, and adrenal gland tissues of rats. ${ }^{26}$ Determination of KET and CLO are usually accomplished by chromatographic techniques but strongly needs a prior sample treatment and enrichment step that has been carried out by liquid-liquid extraction (LLE). ${ }^{27-30}$ There has been no report on the separation and determination of KET and CLO in cow's milk. In order to ensure human food safety, the European Union has set maximum residue limits (MRLs) for some antibiotics, such as fenbendazol 
and enrofloxacin in milk; however, no limit has been ruled out for CLO and KET until now. ${ }^{31}$

Several important parameters such as eluent type and its volume, sample flow rate, sample volume, $\mathrm{pH}$, and ionic strength were optimized and investigated in details. Eluent type and composition showed an important effect on the elution performance and separation efficiency of the analytes hence, a suitable solvent should be selected, which is dependent on the chemical nature of the analyte(s). Five solvents differing in polarity i.e., acetone, ethanol, methanol, ACN and chloroform were tested for eluting KET and CLO. Trials results are shown in Table 2 indicating that acetone showed the best elution efficiency but it is very volatile. Therefore, in the following studies, ethanol was adopted as an eluent due to its less volatility, toxicity and cost.

Table 2. Effect of eluent type on the recoveries of KET and CLO

\begin{tabular}{lccccc}
\hline \multirow{2}{*}{ Drug } & \multicolumn{5}{c}{ Recovery / (\%) } \\
\cline { 2 - 6 } & Acetone & Ethanol & Methanol & Chloroform & Acetonitrile \\
\hline CLO & $72 \pm 8$ & $70 \pm 8$ & $64 \pm 7$ & $67 \pm 5$ & $57 \pm 2$ \\
KET & $86 \pm 4$ & $84 \pm 5$ & $81 \pm 7$ & $0 \pm 5$ & $51 \pm 5$ \\
\hline
\end{tabular}

A series of experiments was designed through changing the volume of eluent ethanol from 1 to $15 \mathrm{~mL}$. The results (as shown in Figure 2) elucidates that the recoveries for drugs increased with an increase in the eluent volume between 1 to $5 \mathrm{~mL}$. When the volume of ethanol was more than $5 \mathrm{~mL}$, the recoveries kept constant. Therefore, in all of the subsequent experiments, $5 \mathrm{~mL}$ ethanol was used as the eluent.

Flow rate of the sample solution not only affects the recovery of analyte(s), but also controls the analysis

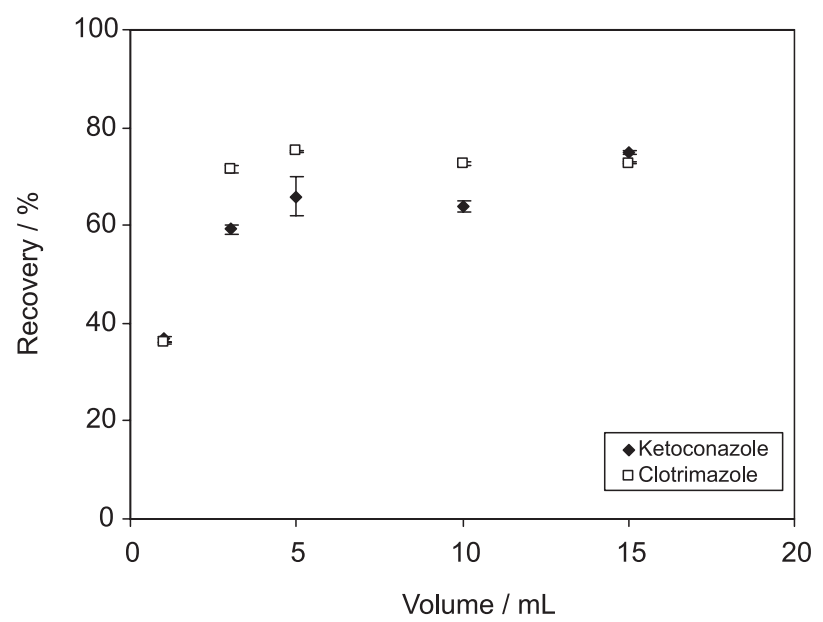

Figure 2. Effect of the eluent volume on the recovery of drugs isolated by SPE cartridge. Conditions: sample concentration $1 \mu \mathrm{gL}^{-1}$ of each analytical species, sample volume $10 \mathrm{~mL}$, volume of ethanol $5 \mathrm{~mL}$, flow rate $1.0 \mathrm{~mL} \mathrm{~min}^{-1}$ time. ${ }^{32}$ In order to save the analysis time and obtain an acceptable result, the flow rate for sample solutions was investigated and optimized in the range of $1-10 \mathrm{~mL} \mathrm{~min}^{-1}$. The effect of flow rate on the recovery of the drugs is shown in Figure 3. According to the results, when the flow rate reached $1 \mathrm{~mL} \mathrm{~min}{ }^{-1}$, the recoveries for two analytes were in the range of $74-87 \%$, which is acceptable in trace analysis. Therefore, in the subsequent analysis, $1 \mathrm{~mL} \mathrm{~min}^{-1}$ flow rate was selected.

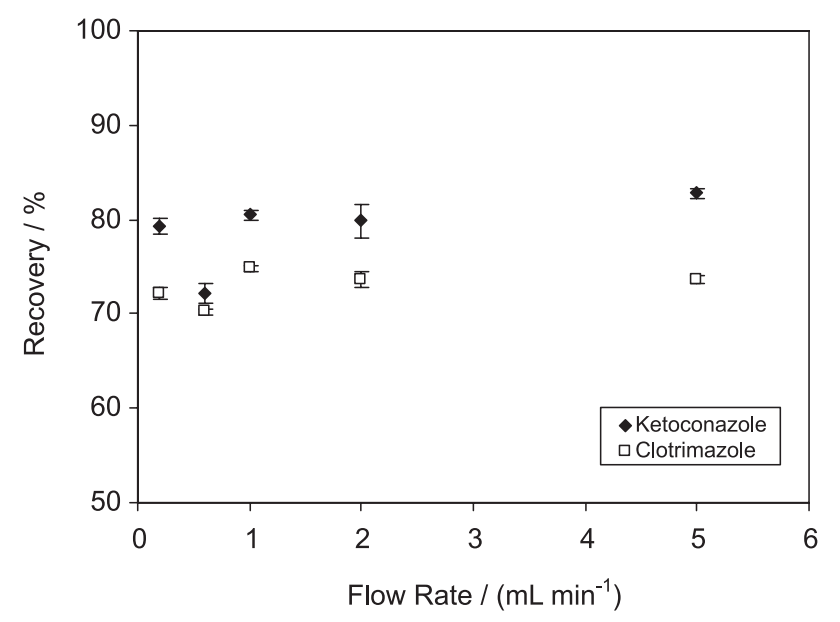

Figure 3. Effect of the eluent flow rate on the recovery of the ketoconazole and clotrimazole by SPE cartridge. Conditions: sample concentration $1 \mu \mathrm{g} \mathrm{mL}^{-1}$ for each compound, sample volume $10 \mathrm{~mL}$, volume of ethanol $5 \mathrm{~mL}$, flow rate $1.0 \mathrm{~mL} \mathrm{\textrm {min } ^ { - 1 }}$

The $\mathrm{pH}$ plays an important role in the solid phase extraction process because it determines the existing ionic state of analytes hence; determines their extraction efficiency. ${ }^{33}$ In this experiment, the effect of $\mathrm{pH}$ was studied in the range of 4.0-8.0. The results are shown in Figure 4. It was observed that the maximum enrichment efficiencies can be achieved for the drugs at $\mathrm{pH}$ 5.8, while the lowest recoveries were obtained at $\mathrm{pH}$ 4.0. Considering $\mathrm{pKa}$ values of 6.3 and 6.5 for CLO and KET, the analytes will be mostly in their cationic state at $\mathrm{pH}$ of 5.8 and the observed extraction inefficiency at the lower $\mathrm{pH}$ values can attributed to instability of these imidazole drugs at strong acidic aqueous solutions. Thus, in the following experiments the $\mathrm{pH}$ of cartridge was adjusted at 5.8.

The effect of ionic strength on the adsorption of drugs on the solid substrate was studied. Ionic strength was adjusted using $\mathrm{NaCl}$ to determine this effect as shown in Figure 5. A series of experiments were designed using $\mathrm{NaCl}$ solution $(1-3 \% \mathrm{~m} / \mathrm{v})$. The results elucidated that using $\mathrm{NaCl}$ to adjust the ionic strength of the eluent solution can improve the extraction recovery significantly to $70.04-84.13 \%$ for both analytical species. However, it was found that using organic solvent as eluent easily causes 


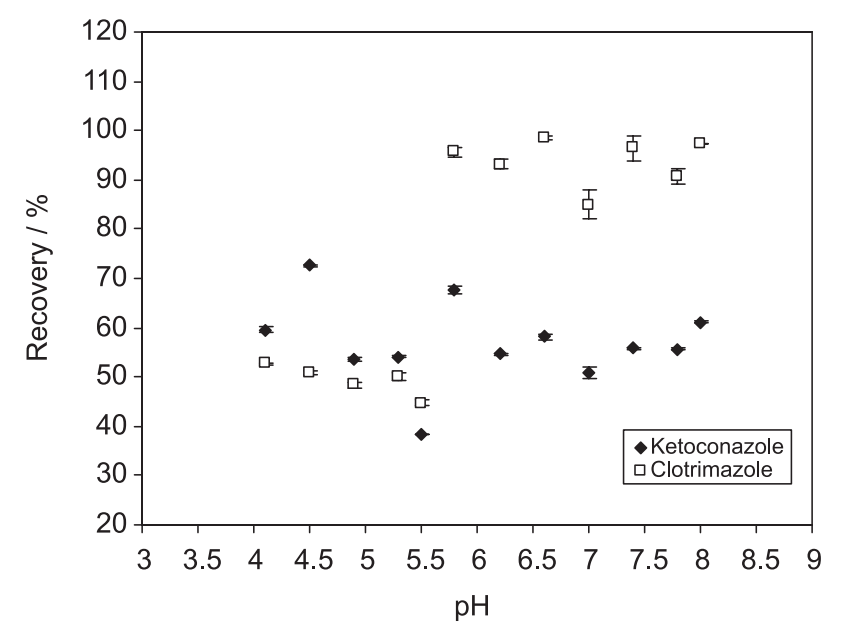

Figure 4. Effect of $\mathrm{pH}$ on the extraction efficiency of the analytes in SPE. Extraction conditions: sample concentration, $1 \mu \mathrm{g} \mathrm{mL} \mathrm{m}^{-1}$ for both compounds, sample volume $10 \mathrm{~mL}$, volume of ethanol $5 \mathrm{~mL}$, flow rate $1.0 \mathrm{~mL} \mathrm{~min}^{-1}$

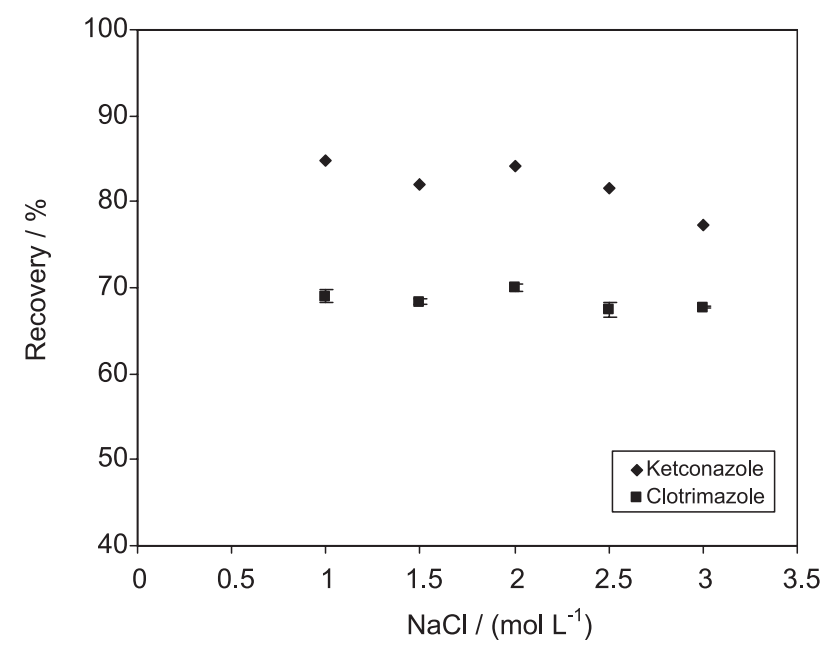

Figure 5. Effect of ionic strength on the recoveries of the analyzed drugs by SPE method. Extraction conditions: sample concentration, $1 \mu \mathrm{g} \mathrm{mL}^{-1}$ for both compound, sample volume $10 \mathrm{~mL}$, volume of ethanol $5 \mathrm{~mL}$, $\mathrm{pH} 5.8$, eluent flow rate of $1.0 \mathrm{~mL} \mathrm{~min}^{-1}$.

salting out when concentration of the salt was $2 \% \mathrm{~m} / \mathrm{v}$ or more therefore; the effect of higher concentrations of $\mathrm{NaCl}$ on the adsorption of drugs has not been suited.

In order to obtain dependable analytical results and a high-enrichment factor, breakthrough volume was determined as a significant parameter which should be brought up for SPE. The effect of sample volume on the recoveries of KET and CLO was investigated in the range

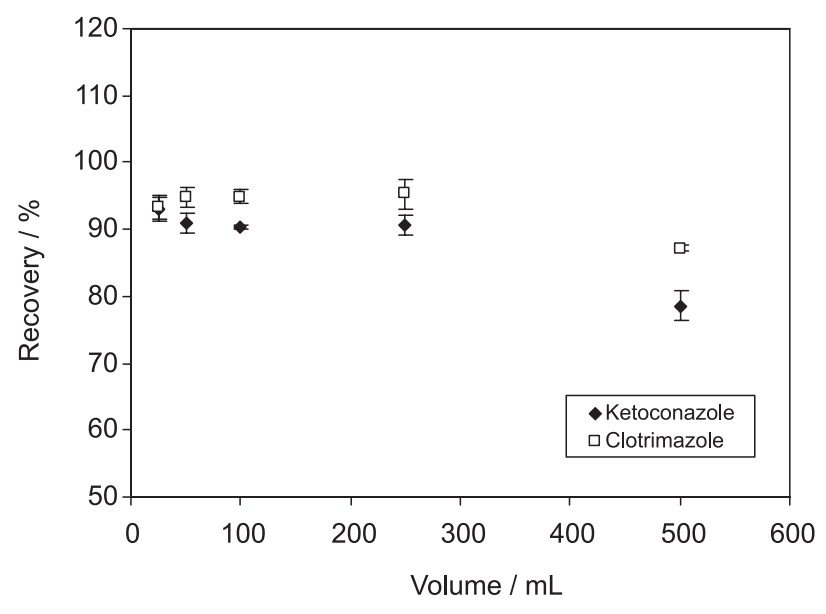

Figure 6. Effect of breakthrough volume on the recoveries of drugs by SPE. Extraction conditions: sample concentration, $1 \mu \mathrm{g} \mathrm{mL}{ }^{-1}$ for each analyte, sample volume $10 \mathrm{~mL}$, volume of ethanol $5 \mathrm{~mL}, \mathrm{pH} 5.8$, flow rate $1.0 \mathrm{~mL} \mathrm{~min}^{-1}$.

of 25-500 mL. Results are shown in Figure 6, which indicates that acceptable enrichment performance was obtained. The recoveries were increased with sample volume in the range of $25-250 \mathrm{~mL}$. The recoveries began to slightly decrease when the sample volume was more than $250 \mathrm{~mL}$. Based on this observation, sample volume of $250 \mathrm{~mL}$ was adopted in further experiments.

\section{Analytical performance}

Under the above optimum conditions, linear range, limits of detection and repeatability of the analytical method were examined (Table 3). Linearity was observed over the range of $0.1-1 \mu \mathrm{g} \mathrm{mL}^{-1}$ for two drugs. Coefficients of correlation $(R)$ ranged from 0.9949 to 0.9993 . The limits of detection (LODs), based on a signal to noise ratio $(\mathrm{S} / \mathrm{N})$ of 3, ranged from $0.01 \mu \mathrm{g} \mathrm{mL}^{-1}$. The RSD was found to be below $7 \%$ for KET and CLO.

\section{Extraction procedure}

KET and CLO were extracted from milk samples spiked with drugs using the described SPE procedure. Milk proteins were denaturated by $15 \mathrm{~mL}$ of ACN and lipids or fat were separated using $10 \mathrm{~mL}$ of $n$-hexane. Separations were achieved using an SPE procedure on $\mathrm{C}_{18}$ cartridges

Table 3. Repeatability (RSD), enrichment factor (EF), linear range (LR), correlation of coefficient $\left(\mathrm{R}^{2}\right)$, and limits of detection (LODs) using SPE method

\begin{tabular}{lccccc}
\hline Drug & $\begin{array}{c}\mathrm{RSD} /(\%) \\
(\mathrm{n}=9)\end{array}$ & $\mathrm{EF} /\left(\mu \mathrm{g} \mathrm{mL} \mathrm{m}^{-1}\right)$ & $\mathrm{LR} /\left(\mu \mathrm{g} \mathrm{mL} \mathrm{mL}^{-1}\right)$ & $\mathrm{R}^{2}$ & $\begin{array}{c}\mathrm{LOD} /(\mu \mathrm{g} \mathrm{mL}-1) \\
(\mathrm{S} / \mathrm{N}=3)\end{array}$ \\
\hline KET & $1.2-6.8$ & $25-250$ & $0.1-1$ & 0.9949 & 0.01 \\
CLO & $0.3-5.3$ & $25-250$ & $0.1-1$ & 0.9993 & 0.01 \\
\hline
\end{tabular}


Table 4. Determination and recovery results for KET and CLO in the spiked milk samples

\begin{tabular}{lccc}
\hline Drug & $\begin{array}{c}\text { Added Levels / } \\
\left(\mu \mathrm{g} \mathrm{mL}^{-1}\right)\end{array}$ & $\begin{array}{c}\text { Found / } \\
\left(\mu \mathrm{g} \mathrm{mL}^{-1}\right)\end{array}$ & $\begin{array}{c}\text { Recovery / } \\
(\%)\end{array}$ \\
\hline KET & 1 & 0.96 & 95.09 \\
CLO & 1 & 1.02 & 101.78 \\
\hline
\end{tabular}

after sample clean up and enhancement. The results are shown in Table 4.

Recovery tests were performed using milk samples spiked with drugs mixture. HPLC chromatogram of the cow's milk and milk samples spiked with $1 \mu \mathrm{g} \mathrm{mL}-1$ of each analyte are shown in Figure 7. Analyzing milk samples gathered from local market $(n=16)$ at different time intervals revealed no cases of pollution with KET and CLO in the detection range of the developed method for samples gathered from local market.

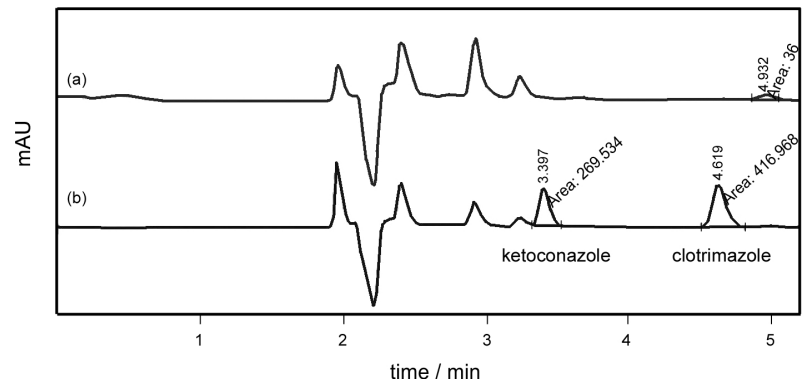

Figure 7. HPLC chromatogram of (a) un-spiked milk samples and (b) sample spiked with $1 \mu \mathrm{g} \mathrm{mL} \mathrm{m}^{-1}$ of each analyte.

\section{Conclusions}

In this paper, a cheap, simple and reliable method is reported for enrichment and determination of KET and CLO in milk samples using solid phase adsorbents. Enrichment factor and detection limit were 25-250 and $0.01 \mu \mathrm{g} \mathrm{mL}{ }^{-1}$, respectively. The calibration curve for drugs in the range of 0.1-1 was linear, and recovery was in the range of 95.9-101.8\%. Relative standard deviations were 1.2-6.8 and 0.3-5.3 for KET and CLO, respectively. Using SPE technique, it is the first report on the extraction and subsequent analysis of KET and CLO from milk by SPE technique.

\section{References}

1. Aerts, M. M. L.; Hogenboon, A.C.; Brinkman, U.A.; J. Chromatogr., B: Anal. Technol. Biomed. Life Sci. 1995, 667, 1.

2. Pontes Netto, D.; Lopes, M. O.; Olivera, M. C. S.; Nunes, M. P.; Machinski Jr., M.; Bosquiroli, S. L.; Benatto, A.; Benini, A.; Bombardelli, A. L. C.; Vedovello Filho, D.; Machado, E.;
Belmonte, I. L.; Alberton, M.; Pedroso, P. P.; Scucato E. S.; Acta Sci., Anim. Sci. 2005, 27, 105.

3. Valenta, C.; Lexer, A.; Spiegl, P.; Die Pharmazie 1992, 47, 641.

4. Hoogerheide, J. C.; Strusiak, S. H.; Taddei, C. R.; Townley, E. R.; Wyka, B. E. J.; J. Assoc. Off. Anal. Chem. 1981, 64, 864.

5. Zegarelli, D. J.; Otolaryngol. Clin. N. Am. 1993, 26, 1069.

6. Odds, F. C.; Milne, L. J.; Gentles, J. C; Ball, E. H.; J. Antimicrob. Chemother. 1980, 6, 97.

7. Heel, R. C.; Brogden, R. N.; Carmine, A.; Morley, P. A.; Speight, T. M.; Avery, G. S.; Drugs 1982, 23, 1.

8. Daneshmend, T. K.; Warnock, D. W; Clin. Pharmacokinet. 1988, 14, 13.

9. Schenck, F. J.; Wagner, R.; Bargo, W.; J. Liq. Chromatogr. Relat. Technol. 1993, 16, 513.

10. Di Pietra, A. M.; Andrisano, V.; Gotti, R.; Cavrini, V.; J. Pharm. Biomed. Anal. 1996, $14,1191$.

11. Wienen, F.; Laug, S.; Baumann, K.; Schwab, A.; Just, S.; Holzgrabe, U.; J. Pharm. Biomed. Anal. 2003, 30, 1979.

12. Bones, J.; Nesterenko, P.; Thomas, K.; Paull, B.; Int. J. Environ. Anal. Chem. 2006, 86, 487.

13. Crego, A. L.; Gómez, J.; Marina, M. L.; Lavandera, J. L.; Electrophoresis 2001, 22, 2503.

14. Kobyliń ska, M.; Kobyliń ska, K.; Sobik, B.; J. Chromatogr., B: Anal. Technol. Biomed. Life Sci. 1996, 685, 191.

15. Gaur, R.; Azizi, M.; Gan, J.; Hansal, P.; Harper, K.; Mannan, R.; Panchal, A.; Patel, K.; Patel, M.; Patel, N.; Rana, J.; Rogowska A.; The British Pharmacopoeia, $6^{\text {th }}$ ed.; Medicines and Healthcare Products Regulatory Agency: London, 2009, Vol. I.

16. Abdelmageed, O. H.; Khashaba, P. Y.; Talanta 1993, 40, 1289.

17. Khashaba, P.Y.; El-Shabouri, S. R.; Emara, K. M.; Mohamed, A. M.; J. Pharm. Biomed. Anal. 2000, 22, 363.

18. El-Saharty, Y. S.; Hassan, N. Y.; Metwally, F. H.; J. Pharm. Biomed. Anal. 2002, 28, 569.

19. El-Bayoumi, A.; El-Shanawany, A. A.; El-Sadek, M. E.; Abd El-Sattar, A.; Spectrosc. Lett. 1997, 30, 25.

20. Crego, A. L; Gómez, J.; Lavandera, J. L.; J. Sep. Sci. 2001, 24, 265.

21. Wienen, F.; Laug, S.; Baumann, K.; Schwab, A.; Just, S.; Holzgrabe, U.; J. Pharm. Biomed. Anal. 2003, 30, 1879.

22. Popović, G.; Čakar, M.; Vučićević, K.; Vladimirov, S.; Agbaba, D.; J. Planar Chromatogr.-Mod. TLC 2004, 17, 109.

23. Szathmary, S. C.; Luhmann, I.; J. Chromatogr., A 1988, 425, 193.

24. Whitehouse, L. W.; Menzies, A.; Dawson, B.; Cyr, T. D.; By, A. W.; Black, D. B.; Zamecnik, J.; J. Pharm. Biomed. Anal. 1994, 12,1425 .

25. De Bruijn, P.; Kehrer, D. F. S.; Verweij, J.; Sparreboom, A.; J. Chromatogr., B: Anal. Technol. Biomed. Life Sci. 2001, 753, 395 .

26. Riley, C. M.; James, M. O.; J. Chromatogr. B: Biomed. Sci. Appl. 1986, 377, 287. 
27. Huang, Q.; Guang-Ji, W.; Jian-Guo, S.; Xiao-Lin, H.; Yi-Hong, L.; Zhang, Q.; Rapid Commun. Mass Spectrom. 2007, 21, 1009.

28. Chen, Y. L.; Felder, L.; Jiang, X.; Naidong, W.; J. Chromatogr., B: Anal. Technol. Biomed. Life Sci. 2002, 774, 67.

29. Hamdy, D. A.; Brocks, D. R.; Biomed. Chromatogr. 2008, 22, 542.

30. Wienen, F.; Laug, S.; Baumann, K.; Schwab, A.; Just, S.; Holzgrabe U.; J. Pharm. Biomed. Anal. 2003, 30, 1879.
31. Veau De, E. J.; Pedersoli, W.; Cullison, R.; Baker, J.; J. Vet. Pharmacol. Ther. 1998, 21, 437.

32. Cai, Y.; Jiang, G.; Liu, J.; Zhou, O.; J. Anal. Chem. 2003, 75, 2517.

33. Zhou, Q. X.; Ding, Y. J.; Xiao, J. P.; Anal. Bioanal. Chem. 2006, 85, 1520.

Submitted: November 27, 2010

Published online: June 9, 2011 